\title{
On the preparation of creatine, \&c
}

\section{Dr. Gregory}

To cite this article: Dr. Gregory (1848) On the preparation of creatine, \&c, Philosophical Magazine Series 3, 33:220, 164-165, DOI: 10.1080/14786444808646071

To link to this article: http://dx.doi.org/10.1080/14786444808646071

$$
\text { 册 Published online: } 30 \text { Apr } 2009 .
$$

Submit your article to this journal

Шll Article views: 1

Q View related articles 두 
$\left.\mathrm{H}^{23} \mathrm{~N}^{2} \mathrm{O}^{7} \mathrm{HO}\right) \mathrm{HO}^{2} \mathrm{PO}^{5}$. A double phosphate of brucia and soda was also formed, but could not be obtained perfectly pure.

Phosphate of Quinine, with three equivalents of quinine.-By digesting quinine with phosphoric acid, a solution of this salt is obtained which becomes a solid mass of silky needles on cooling. They are extremely soluble in hot water, and are quite neutral to test-paper. They gave by analysis a result corresponding with $3\left(\mathrm{C}^{20} \mathrm{H}^{12} \mathrm{NO}^{2}\right.$ HO) $\mathrm{PO}^{5}$. These results the author considered sufficient to establish the fact, that the phosphates of the organic alkalies agree in their constitution with the inorganic salts of that acid; and he concluded his paper by observing, that the relation of these bases to phosphoric acid might be made use of as a means of classifying them. Thus quinine, which replaces three equivalents of water in phosphoric acid, might be compared to oxide of lead and the oxides of the heavy metals ; brucia might represent the inorganic alkalies; while strychnia, which under ordinary circumstances replaces only one equivalent of water, belongs to a class which has no analogue among the series of inorganic bases.-R. S. Edinburgh. Jameson's Journal, July 1848.

\section{ON THE PREPARATION OF CREATINE, \&C. BY DR. GIRGORY.}

After some remarks on the present state of animal chemistry, the author commenced by giving a brief account of the recent discoveries of Liebig in regard to the constituents of the "juice of flesh," or the liquid contained in the substance of the muscles, which is distinguished from the blood by the large quantity of free acid which it contains. This remarkable animal fluid has been found by Liebig to contain phosphoric and lactic acids in large quantity, inosinic acid in small proportion, and some other acids not yet studied; also pot. ash in large quantity, with a little soda, a considerable proportion of magnesia, and a little lime, chloride of potassium, with a little chloride of sodium, and, besides some compounds of animal origin not yet investigated, the new base Creatinine, and the very remarkable substance Creatine, first discovered by Chevreul, but in vain sought for by Berzelius and other ehemists.

He then described the process, essentially that of Liebig, by which creatine is extracted from the flesh of quadrupeds, birds and fishes, in all of which hitherto tried it has been found, although in small and variable quantity. A table was exhibited, showing the per-centage obtained from different kinds of flesh and fish; and the result was, that this interesting substance may be most easily and cheaply prepared from fish, especially the cod, herring, salmon and mackerel, all of which yielded much more than beef or horse-flesh, and nearly as much as fowl, which was the most productive. The maximum proportion of creatine was 3.2 per 1000 parts of flesh; the average about $1 \cdot 5$ per 1000 .

The author stated that he had found inosinic acid only in the flesh of fowl and turkey; and he is informed by Baron Liebig, that it is quite possible that this acid may also have been confined to the flesh of fowls in his experiments, as it was often absent, although he cannot now ascertain the cases in which it was present. 
He concluded by stating, that as creatine is found in the urine along with creatinine, it appears to be, in part at least, a substance intended for excretion. Its crystalline character renders this probable; and at all events, if it has any function to perform in the body, that function is not yet known. It must be regarded, in the mean time, as one of the numerous series of less complex products derived from the decomposition, in the body, of the effete tissues; and although we cannot yet produce it artificially, yet from the rapid progress recently made in the study of the products of decomposition of the albuminous substances, we may hope soon, not only to do this, but also to discover, from these products, the true formulæ of the albuminous compound.-Ibid.

\section{RESEARCHES ON THE CONSTITUTION OF THE ATMOSPHERE.}

M. Doyère having had particular occasion to examine the phænomena of respiration of man and animals exposed to the influence of the vapour of æether, he was induced to try the protochloride of copper as an absorbent of oxygen in gaseous mixtures. The favourable results of the employment of this reagent having induced him to pursue the study of eudiometry, he succeeded in effecting a combination of instruments with simple means of correction and easy management, which gave the original volume of a gas, and that of the residue which any ahsorbent leaves, within a ten-thousandth part.

The author was surprised to find that his method indicated larger proportions of oxygen than those generally admitted, and that even among them considerable variations occurred. M. Doyère continued his operations for four months, and the results proved that the composition of the air varies incessantly. In general the variation is slight, and the proportions of oxygen varying between 208 and 210 parts in 1000 ; but this variation was found to go as low as 205 , and as high as 212. These great differences never occurred suddenly; the quantity having diminished or increased as gradually as consists with such a description of facts. M. Doyère shows that his results harmonize perfectly with those of MM. Boussingault and Dumas obtained at Paris; - with those which were obtained by M. Stas at Brussels, and with the great work achieved by $M$. Lewy with respect to the air of the North Sea, and that of Guadaloupe. He also proves that Dr. Prout's experiments on the weight of the air, and those published by M. Regnault, agree with his view of the subject, and prove that the air is continually varying.

He shows also, that the densities of oxygen and nitrogen given by M. Regnault do not agree with the composition of the air when stated to contain only 209 of oxygen; and that they indicate 213 thousandths of oxygen if the mean density of nitrogen be adopted, and 212 to 215 if the extreme densities resulting from the experiments of M. Regnault be preferred.-Comptes Rendus, Février 14, 1848.

RESEA RCHES ON ESSENTIAL OILS. BY M. C. GERHARDT.

Oil of Chamomile (Anthemis nobilis).-This oil, like the greater number of liquid essential oils, is a mixture of two principles, one 